\title{
SOCIAL PROGRESS AND INTEGRAL HUMAN DEVELOPMENT: ON HAPPINESS, WELFARE AND DIGNITY
}

In Happiness And Contemporary Society : Conference Proceedings Volume (Lviv, March, 20-21, 2021). Lviv: SPOLOM, 2021. P. 87-92. https://doi.org/10.31108/7.2021.18

ISBN 978-966-919-697-2

ДОБКО Тарас

\section{СУСПІЛЬНИЙ ПОСТУП І ЦЛЛСНИЙ ЛЮДСЬКИЙ РОЗВИТОК: ПРО ЩАСТЯ, ДОБРОБУТ І ГІДНІСТЬ}

// Щастя та сучасне суспільство : збірник матеріалів міжнародної наукової конференції (Львів, 20-21 березня 2021 р.). - Львів : СПОЛОМ, 2021. С. 87-92. https://doi.org/10.31108/7.2021.18

ISBN 978-966-919-697-2 
https://doi.org/10.31108/7.2021.18

\author{
DOBKO Taras \\ Ph.D., Associate Professor, \\ First Vice-Rector of Ukrainian Catholic University (Lviv, Ukraine)
}

\title{
SOCIAL PROGRESS AND INTEGRAL HUMAN DEVELOPMENT: ON HAPPINESS, WELFARE AND DIGNITY
}

This article examines philosophical assumptions of whether and how happiness could become a goal of political action and standard for assessing government's performance. It is argued that solidarity and care for the common good require the political economy of citizenship balanced with affirmation of the dignity of the human person in the form of basic human rights. The rule of law and fair procedures should be complemented with the concern for character development into citizenship and mature civic commitment. This unfolds both in faith-based and secular attempts to imagine and measure human development in terms beyond GDP index and economic statistics. To succeed these attempts must be based on an adequate anthropology, draw their strength from a sound moral source and inspire mature ethical agency. Catholic social thought conceives of integral human development as a way of envisaging social arrangements that foster flourishing of the whole person and each person. It is based on the vision of the human being as an image of God and draws its energy from the idea of "good society" in which respect for the dignity of the human person and care for the common good of all people are central to political and social life.

KEY WORDS: Integral human development, common good, dignity, good society, human rights, social progress

\author{
ДОБКО Тарас \\ доктор філософії, доцент, перший проректор, \\ Украӥнський католицький університет (Львів, Украӥна)
}

\section{СУСПІЛЬНИЙ ПОСТУП І ЦІЛСНИЙ ЛЮДСЬКИЙ РОЗВИТОК: ПРО ЩАСТЯ, ДОБРОБУТ І ГІДНІСТЬ}

Щастя як ціль публічної політики

«Ми вважаємо за самоочевидні істини, що всіх людей створено рівними; що Творець обдарував їх певними невідчужуваними правами, до яких належать життя, свобода і прагнення щастя; що уряди встановлюють між людьми на те, щоб забезпечувати ці права, а влада урядів походить із згоди тих, ким вони управляють; що в кожному випадку, коли якась форма правління стає згубною для такої мети, народ має право змінити або скасувати ії і встановити новий уряд, спираючись на такі принципи та організовуючи його владу в такі способи, які видаються народу найдоцільнішими для осягнення своєї безпеки і щастя» [2].

Цей уривок 3 Декларації незалежності США описує «американську мрію» створити щось цілковито нове в тодішньому світі - good society (добре суспільство), в якому життя, свобода і прагнення щастя громадянина є в центрі 
уваги урядування і суспільної взаємодії. Та чи може щастя бути ціллю політики? I в чому таке щастя могло би полягати? Якщо, з одного боку, йдеться про прагнення щастя як невідчужуване право громадянина, а з іншого - про щастя народу, для здобуття якого встановлюють відповідні способи організації його влади...

Життя людини у ліберальному світі годі уявити без концептуалізації “прав людини" - на життя, свободу слова і віросповідання, власність, працю і освіту тощо. Ця мова $є$ підгрунтям для взаємодії людей в умовах вільних, демократичних i ринкових суспільств. Мейнстрім ліберальної думки вбачає головні ознаки доброго суспільства у дотриманні індивідуальних прав і чесній участі всіх в суспільній грі за однаковими правилами. Лібералізм грунтується на переконанні про гуманістичний потенціал людської істоти, її спроможності розпізнавати добро і самостійно подбати про нього. Лише треба, мовляв, усунути зовнішні перешкоди, які сковують людські можливості самовдосконалення.

А тому “добре" суспільство не повинно пропагувати, а тим більше нав’язувати своїм громадянам жодні життєві цілі. Радше воно має творити для них нагоду переслідувати їхні власні цілі. Передумовою для індивідуального проекту щастя $\epsilon$ забезпечення такої ж свободи для решти. Тож таке суспільство керується принципами, які не залежать від жодної конкретної концепції щастя. Як вірно зауважує Майкл Сандел, ці принципи грунтуються на уявленні, що справедливість $\epsilon$ моральною категорією, незалежною і навіть більш засадничою від поняття блага $[6,157]$. Іншими словами, добре суспільство стає таким не тому, що націлене на якусь благу ціль чи мету, а тому, що відмовляється від такого підходу - не надає перевагу жодній 3 конкурентних цілей. I опирається на дотримання процедурної справедливості - верховенства права і чесних правил гри для всіх.

Добре суспільство покликане розвивати спроможність людей простувати власною неповторною дорогою змістовного життя шляхом постійного розширення людських свобод. Не слід жертвувати індивідуальними правами на користь загального благополуччя. Не можна виводити ці права 3 якоїсь конкретної концепції доброго життя. Будь-який інший підхід привів би до невдачі 3 пошануванням людей, як вільних істот спроможних на самостійний вибір, i ставився би до них як до об'єктів, а не суб'єктів, як до засобу, а не мети політики. Завданням урядування $є$ у такому разі забезпечити нейтральне середовище у вигляді прав людини, де кожна людина вільно зможе обирати власні цінності і життєві цілі [6,9]. Майкл Сандел називає цей різновид лібералізму політичною філософією «волюнтаристської свободи».

На прикладі США видно, що такий лібералізм не обов'язково має бути партійним. Демократи апелюють до ідеї нейтральності уряду, щоб позбутися практики молитви в публічних школах чи послабити моральні аргументи за обмеження наукових експериментів. Республіканці роблять те ж, коли виступають проти введення «моральних гальм» на ринкові правила гри в економіці [6,9]. Коли ж демократи покладають на уряд відповідальність за забезпечення громадян гідним рівнем доходу, житла, освіти і медичних послуг, вони не вважають, що при цьому нав'язують всім якесь загальне уявлення про щастя, а лише стверджують, що економічно неблагополучні люди не здатні належним чином реалізувати свій вибір цілей в інших ділянках життєдіяльності. Коли ж республіканці протестують проти підвищення податків, вважають це нелегітимним примусом громадян i запереченням їх права 
вільно розпоряджатися власноруч заробленими грішми, вони знову ж таки апелюють до волюнтаристського бачення політичної свободи $[6,10]$.

Відмовляючись в ім'я свободи від плекання спільної візії “доброго життя”, “лібералізм” насаджує уявлення про людину як атомізовану істоту, яка керується у практичному житті в першу чергу своїм інтересом і відстоює його через апеляцію до ii непорушних індивідуальних прав. Якщо ж права $є$ нашими “козирними картами" у взаємодії з іншими, ми крок за кроком виробляємо уявлення про себе, як про автономних і самодостатніх індивідів, не зв'язаних жодними обов'язками, які би випереджали наші права.

Таке уявлення про автономне "я" впливає на нашу здатність бути частиною спільноти. Звісно, ми спроможні ставати членами добровільних асоціацій. А от із спроможністю уявляти себе частиною спільноти, сформованої на основі моральних зв'язків, які випереджають нашу добровільну згоду, є проблема. Така спільнота апелює не лише до інтересів своїх учасників, а до їхніх “я”, формує їхню ідентичність і впливає на неї. Ми ж часто не готові долучатися до спільноти, де наша самість є частиною “інвестиції” [6,163]. Бо, мовляв, жоден проект не повинен бути аж настільки істотним, щоб відмова від нього могла поставити під питання мою ідентичність. Бо жодна роль чи справа не повинна визначати мене настільки, щоб я не міг себе уявити без неї.

Як наслідок, одним 3 найскладніших завдань в ліберальному публічному просторі стає пошук балансу між забезпеченням індивідуальних прав людини і суспільного інтересу. Визначення точки балансу значною мірою залежить від наших уявлень про справедливість; про сенс і цінність соціальних практик та інститутів, що нас оточують; про співвідношення між громадянськими правами i обов'язками. Що більш фрагментованим, поляризованим і різнорідним стає суспільство, тим складніше встановлювати, в чому полягає цей суспільний інтерес, i приймати відповідні політичні рішення. В суспільних обставинах, опанованих логікою споживацтва, такий баланс майже неможливо осягнути. Як тільки 3 поля зору зникає горизонт обов'язків людської особи як члена родини, громадянина, частини природного середовища, релігійної істоти, дискурс прав людини вироджується у практику скарг і образ. Людина починає спілкуватися з іншими людьми і світом мовою вимог і претензій, забаганок і нарікань.

Як наслідок, стверджує Майкл Сандел, в соціальних практиках відбувається зсув від філософії спільного блага до філософії чесних процедур, від національної до процедурної республіки, від політичної економії громадянства до політичної економії росту $[6,19]$.

А хто “рулить”: економіка чи демократія?

Таке уявлення про атомізовану людину та іiї свободу найкраще пасує до логіки ринкової економіки і веде до тлумачення поступу людських спільнот в термінах внутрішнього валового продукту. Як наслідок, дебати про людське благополуччя зводять до матеріального добробуту і ведуть передусім про те, як краще досягти економічне зростання і більш чесно розподілити його плоди, як збалансувати ризики інфляції і безробіття, якою має бути справедлива система оподаткування i що $є$ пріоритетним при використанні бюджетних ресурсів. Економічний ріст i матеріальний достаток стає головною ціллю i мірилом 
успішності політики. Майкл Сандел називає цей підхід політичною економією росту і дистрибутивної справедливості $[6,17]$.

Альтернативою є республіканський ідеал $[6,10]$, за яким політична свобода залежить від спроможності людини до ії участі в самоуправлінні, а та - від наявності громадянських чеснот, зрілого розуміння публічних справ, почуття відповідальності за спільне добро, прийняття на себе обов'язків за громаду. Можна бути морально зобов'язаними перед якоюсь спільнотою, навіть якщо ми не брали на себе це добровільно. Обов'язок лояльності виникає просто внаслідок того, ким ми $\epsilon$ - чиєюсь донькою, другом, членом парафіяльної спільноти, міщанином, громадянином країни. Людина не $\epsilon$ одиноким островом. На неї впливають інші люди, традиція, культура. Свобода ж передбачає можливість здійснення людьми впливу на ті сили, які самі впливають на їх спільну долю. Вільна людина не може бути просто іграшкою в руках віддалених та анонімних сил, які перебувають повністю поза межами пї контролю. Тому уряд не повинен залишатися нейтральним щодо цілей, що їх сповідують громадяни, концепції «доброго життя», формування в громадян якостей, необхідних для самоуправління $[6,10]$.

Майкл Сандел називає такий підхід політичною економією громадянства [6,11]. На його думку, економічні і політичні інститути потрібно оцінювати за їх схильністю сприяти чи заважати появі моральних якостей і громадянських чеснот, необхідних для самоуправління і демократії. Іншими словами, економічна політика - це не тільки про споживання і чесний доступ до нього, а й про самоуправління [6,11].

Це перегукується з відомими словами Роберта Кеннеді: «Надто багато i надто довго ми приносили наші особисті якості і спільні цінності в жертву матеріальному накопичуванню. Наш ВВП перевищив 800 мільярдів доларів за рік, але він - якщо по ньому судити про Сполучені Штати Америки - складається із забруднення атмосфери, реклами сигарет, жертв автокатастроф, яких забирає 3 наших доріг швидка допомога. Він складається із замків на наших дверях $\mathrm{i}$ в'язниць для тих, хто зламує ці замки. В нього входить безладне знищення наших заповідних лісів, цього дива природи. В нього входять напалм, і ядерні боєголовки, і поліцейські бронемашини, що розганяють демонстрантів в наших містах... ВВП не може забезпечити для наших дітей здоров'я, якісну освіту чи радість від гри. В нього не входить ні краса нашої поезії, ні міцність наших шлюбів, ні інтелектуальний рівень наших публічних дебатів, ні порядність наших публічних посадових осіб. Його не можна вважати мірилом ні нашого розуму, ні нашої відваги, ні нашої мудрості, ні наших знань, ні нашого милосердя, ні нашої любові до батьківщини. Одним словом, ВВП - це мірило всього, за винятком того, заради чого варто жити. Він може розказати про Америку все, за винятком того, чому ми пишаємося тим, що ми американці» [3].

Цілісний людський розвиток як критерій поступу

В енцикліці «Поступ народів» Папа Павло VI ввів поняття цілісного людського розвитку: «Поступ стосується не тільки зростання економіки. Щоб називатися справжнім поступом, він має бути цілісним, тобто сприяти розвитку кожної людини й усієї людини» [5]. По суті, концепція цілісного людського розвитку описує явище “гідного життя", передумовою чого $\epsilon$ визнанням багатовимірної природи людської істоти та важливості ії правильних стосунків 3 іншими людьми в суспільстві й з усім Божим творінням. Йдеться про процвітання 
всієї людини і кожної людини у справедливому і мирному суспільстві. Цей підхід грунтується на цілісному розумінні благополуччя людини, що включає економічний, соціальний, політичний, культурний, екологічний і духовний виміри іiі життя. Він веде до визнання священності людського життя і гідності людської особи в соціальних, політичних, економічних і правових інституціях суспільства. Клеменс Седмак висловлює цю концепцію у формі двох імперативів: «Нікого не залишати позаду! Упевніться, що кожен вимір людини взято до уваги!» [7] Цілісний розвиток людини використовують як засадничу концепцію для оцінки і вирішення викликів, пов'язаних із гідним людським життям і соціальним поступом.

Консенсус, що людський розвиток не можна адекватно описати лише 3 урахуванням ВВП чи інших економічних факторів, поступово сформувався і у світському середовищі. Добре відомий «Індекс кращого життя» [4] від ОЕСР, в якому відображено визнання, що якість життя залежить не лише від холодних показників ВВП та економічної статистики. Відомі також доволі екстравагантні рішення на зразок намагання уряду Бутану замінити валовий внутрішній продукт (ВВП) індексом валового національного щастя (ВНП) як мірила оцінки державної політики i результатів діяльності уряду. Ще однією важливою спробою диверсифікувати оцінку поступу людства було створення Індексу людського розвитку (ІЛР) [9]. Цей підхід націлений на зміцнення спроможності людини йти власною життєвою дорогою. ІЛР грунтується на простому переліку можливостей, орієнтованих на досягнення базової якості життя - уникнення голоду та здобуття базового стану здоров'я та освіти.

Важливо зазначити, що у грудні минулого року ПРООН випустила звіт про людський розвиток» під назвою «Наступна межа. Людський розвиток і антропоцен». У звіті йдеться про тісний взаємозв'язок планетарних і соціальних дисбалансів. I, як наслідок, закликають перейти «від вирішення дискретних розрізнених проблем до навігації багатовимірних, взаємопов'язаних і все більш універсальних труднощів» $[10,5]$. Звіт вводить концепцію «базованого на природі людського розвитку», завдяки чому процвітання людини може відбуватися поряд зі зменшенням тиску на планету. «Для багатьох країн все важливішими стають питання, які стосуються не так загального розміру пирога, а відносного розміру його скибок. У звіті ж за цей рік ... ми також турбуємось про піч» $[10,6]$. На думку авторів, справедливість, інновації і відповідальність за природу мають стати ключовими в розумінні того, що означає жити добре. У звіті підкреслюють, що одним з ключових питань людського розвитку $є$ подолання бідності у всіх іiі формах - «тверде зобов'язання нікого не залишати позаду в процесі поступу» $[10,6]$.

\section{Висновок}

Такий людський поступ і розвиток $є$ надзвичайно амбітною метою. Чи може він слугувати реалістичною ціллю практичної політики, а не утопічним i недосяжним ідеалом, що всім буде щастя? Ми побачили, що, як мінімум, він вимагає адекватної антропології та політичної економії громадянства.

Однак, крім того, велике значення для політичної практики має наявність сильного морального джерела. Як наголошує Крістіан Сміт, обгрунтування i підтримка відданості високим етичним стандартам, ідеалам і практикам, які $€$ складними й коштовними для виконання (наприклад, ідеї цілісного людського розвитку) залежить від наявності «розповіді, що задовільно пояснює скептикам 
реальність і підстави, що лежать в основі таких вимогливих зобов'язань i переконань» $[8,53]$. Щоб сприймати іншу людину не як конкурентна за ресурси, а як брата чи сестру, а природу - не як сировинну базу, а як дім, потрібні моральні сили і духовна енергія, що їх годі отримати суто із секулярних джерел. Надихнути на безкорисливу турботу про іншу людину та іï щастя, про природу і творіння може бачення людської особи не меншого масштабу, ніж те, що пропонує Христос - як істоти, сотвореної на образ і подобу Бога. Не дивно, що на думку Джона Кавадіні, «вибір на користь бідних - це категорія, що походить 3 одкровення, а не 3 наукового розуму. Це вчення не випливає зі світських дисциплін чи навіть 3 філософії» [1].

Духовна енергія для такого подвигу - до служіння спільному добру i посильного внеску в "розвиток цілісної людини і всіх людей" - не з'явиться сама по собі, нізвідки. Для цього потрібне усвідомлення, що всі люди $є$ не випадковими сиротами в байдужому до нас космосі, не просто членами одного біологічного виду чи носіями розумної свідомості, а дочками і синами єдиного Отця. Без такого навернення можна розраховувати хіба що на хитку суспільну рівновагу егоїстичних імпульсів, приватних фінансових інтересів, класових антагонізмів, племінних чи кланових претензій, образ і скарг, владних амбіцій. Лише у перспективі відкритості на приналежність до спільної родини, яка походить від єдиного Бога, з'являється надія не просто на тимчасове перемир'я, а на суспільний мир. 3'являється бажання і сила над цим працювати і не опускати руки навіть перед викликами несправедливості, ворожості, агресії і ненависті.

\section{ЛITЕРАТУРА}

1. John Cavadini. Black Lives and the Preferential Option for the Poor, February 08, 2021 https://churchlifejournal.nd.edu/articles/black-lives-and-the-preferentialoption-for-the-poor/

2. Declaration of Independence https://www.archives.gov/founding-docs/declarationtranscript

3. Robert F. Kennedy. Remarks at the University of Kansas, March 18, 1968 https://www.jfklibrary.org/learn/about-jfk/the-kennedy-family/robert-fkennedy/robert-f-kennedy-speeches/remarks-at-the-university-of-kansas-march-18-1968

4. OECD Better Life Index http://www.oecdbetterlifeindex.org/

5. Pope Paul VI. Populorum progressio. Encyclical on the development of peoples, March 26, $1967 \quad$ http://www.vatican.va/content/paulvi/en/encyclicals/documents/hf_p-vi_enc_26031967_populorum.html

6. Michael J. Sandel. Public Philosophy: Essays on Morality in Politics. Harvard University Press: Cambridge, Massachusetts, 2006.

7. Clemens Sedmak. One concept, two imperatives, April 23, 2020 https://keough.nd.edu/one-concept-two-imperatives/

8. Christian Smith. Atheist Overreach: What Atheism Can't Deliver, Oxford University Press, 2019

9. UNDP Human Development Index http://hdr.undp.org/en/content/humandevelopment-index-hdi

10. UNDP Human Development Report 2020. The Next Frontier. Human Development and the Anthropocene, December 2020 http://hdr.undp.org/sites/default/files/hdr2020.pdf 